\title{
Current and Future Nanotechnology Applications in the Management of Melanoma: A Review
}

\author{
Hawys Lloyd-Hughes ${ }^{1,2}$, Andreas E Shiatis ${ }^{1 *}$, Amit Pabari ${ }^{1,2}$, Ash Mosahebi $^{1,2}$ and Alexander Seifalian² \\ ${ }^{1}$ Plastic and Reconstructive Surgery Department, Royal Free Hospital, London, UK \\ ${ }^{2}$ Division of Surgery and Interventional Sciences, University College, London, UK
}

\begin{abstract}
Melanoma is a common malignancy with a high survival rate amongst those diagnosed early. The management of advanced disease is challenging, and current chemosurgery techniques have minimal effect on survival. Nanotechnology, offers great potential in revolutionizing the management of melanoma. New molecules and nanoparticles are designed worldwide in an aim to improve the diagnosis and spread to sentinel lymph nodes and other organs. Novel drug delivery systems are formulated to optimise the distribution and pharmacokinetics of chemotherapeutic agents while reducing their toxic effects. The scope of such molecules extends to therapeutic applications including photodynamic and photothermic therapy where light is converted to heat to combat neoplastic lesions; immunotherapy where nanoparticles are used as immunomodulators or vaccines against cancer cells; and gene therapy which targets pro-oncogenes on signal transduction pathways. This review paper presents current knowledge of the use of nanotechnology in the management of cancer, with a focus on melanoma.
\end{abstract}

Keywords: Melanoma; Nanotechnology; Quantum dots; C-dots; Theranotics; Photodynamic therapy; Immunomodulators; Malignancies; Epidermis

\section{Introduction}

Nanotechnology is a rapidly developing field involving the interdisciplinary study of materials that, at an atomic level, have a size of less than $100 \mathrm{~nm}$. Advances in nanotechnology offer an unprecedented ability to study and manipulate molecular interactions at a sub-cellular level leading to the development of new strategies to image but also treat human disease including cancer.

Skin cancer is the commonest group of malignancies diagnosed in humans. Of this group, malignant melanoma, originating from melanocytes in the basal layer of the epidermis, is the most aggressive form, ranking 6th amongst all diagnosed malignancies [1]. During the last decades, malignant melanoma has become a significant global health problem, particularly amongst Caucasian populations, in which the incidence rate has risen inexorably, nearly quadrupling over the last 20 years [2].

Traditionally, the management of malignant melanoma is considered challenging: its diagnosis is difficult and often patients present late. If managed early, cure rates as high as $97 \%-99.8 \%$ after chemosurgery have been reported [3]. Advanced stages of melanoma are characterized by widespread metastases and currently stage IV disease reports survival rates of less than $10 \%$ in 5 years [4]. Conventional treatment options for advanced stages such as surgery, chemotherapy and immunotherapy, although effective in cases of nonmetastatic melanomas, are of limited value to disseminated disease [5].

The staging of melanoma is standardized according to the American Joint Committee on Cancer [AJCC] system. Tumour thickness, reported as Breslow Thickness (BT), plays a major role in staging in addition to the ulceration and mitotic rate, the number of nodes involved and the extent of the distant metastasis [6]. Although early stage melanomas (IA) require only a wide local excision, larger or poorly differentiated tumours which are staged as IB and above are offered a Sentinel Lymph Node Biopsy (SLNB), as per the British Association of Dermatology (BAD) guidelines [6].

SLNB is a purely diagnostic test that requires the injection of a radioactive agent and a blue dye to isolate the sentinel lymph node that drains the skin affected by melanoma. An invasive test, SLNB requires the excision of the sentinel node which is consequently biopsied in an attempt to identify melanoma deposits. Although a test of no proven therapeutic value, SLNB comes with inevitable documented surgical risks, the possibility of failure of isolating a sentinel node and a falsenegative result.

The MSLT1 study, an international randomized trial on the effectiveness of SLNB on melanoma, has highlighted that although $79.2 \%$ of patients did not have nodal disease; those with a positive result $(20.8 \%)$ had improved survival rates [7]. It is therefore not a coincidence that nanotechnologists have focused on identifying new approaches to SLNB, which are less invasive; carry less surgical morbidity and higher specificity.

More advanced cases require further invasive diagnostic tests. For Stage IIIB and above, CT scans of head, chest, abdomen and pelvis are recommended while Stage IV requires further tests including LDH levels and PET scans [6]. Although not as invasive as SLNB, CT scans carry the inherent exposure to substantially high levels of radiation. Furthermore surgical resection for such cases, (lymph node clearance and/or excision of other melanoma deposits), can be particularly extensive with debilitating consequences for the patient and significant morbidity. The field of photodynamic therapy and laser ablation in association to newly developed nanoparticles might have a role in the future surgical management of melanoma reducing surgical complications and sparing normal native tissue.

*Corresponding author: Andreas E Shiatis, BA, MBBS, MRCS, Plastic Surgery $\mathrm{SpR}$, Plastic and Reconstructive Surgery Department, Royal Free Hospital, London, UK, Tel : 06109/33261; E-mail: dr.andreas.shiatis@gmail.com

Received October 19, 2015; Accepted October 27, 2015; Published November 10,2015

Citation: Lloyd-Hughes H, Shiatis AE, Pabari A, Mosahebi A, Seifalian A (2015) Current and Future Nanotechnology Applications in the Management of Melanoma: A Review. J Nanomed Nanotechnol 6: 334. doi:10.4172/2157-7439.1000334

Copyright: () 2015 Lloyd-Hughes $\mathrm{H}$, et al. This is an open-access article distributed under the terms of the Creative Commons Attribution License, which permits unrestricted use, distribution, and reproduction in any medium, provided the original author and source are credited. 
It is becoming increasingly clear that melanoma, like many other cancers, arises due to genetic aberrations that alter signaling pathways that control mitosis, meiosis and apoptosis [8]. Novel therapeutic approaches based on our increasing understanding of the molecular changes that underlie the development of melanoma have recently positively changed the treatment landscape of this disease. Mutation-driven drug development is an ever-optimistic field for the pharmacological treatment of melanoma and has led to the introduction of therapies including Ipilimumab, the BRAF inhibitor Dabrafenib and the MEK inhibitor Trametinib [5].

Chemotherapy itself comes with dire systemic complications that are often so extensive that make the management of advanced cancer futile. Nanotechnology hopes to improve adjuvant oncological approaches to melanoma by creating drug delivery systems that are safe and effective, but at the same time targeted to cancer cells, sparing normal, benign cells.

Immunomodulation is another key advancement in the treatment of malignant melanoma. Immunotherapy involves the blockage of certain monoclonal antibodies expressed solely by the tumour, inhibiting immune tolerance towards the melanoma and possibly leading to its regression. The commonest reported immunomodulators in melanoma are interleukin (IL)-2 and interferon (IFN)-alpha [9-12]. Ipilimumab is one such antibody that is currently in use in Europe and the USA. Such antibodies can also be used as cell targeting systems to further reduce systemic chemotherapeutic effects.

Nanotechnology has the potential to lead to great advances in the arena of melanoma research, increasing the diagnostic and treatment armamentarium, further revolutionizing the clinical approach to melanoma. The epitome of nanotechnology is the evolution of a new field known as theranotics: the design of a single particle which can be used to diagnose stage but also treat cancers such as melanoma. The aim of this paper is to provide an update of current and future uses of nanotechnology in the management of cutaneous melanoma.

\section{Methods}

A literature search was performed through Medline, EMBASE, Cochrane Database and Google Scholar for any previous research applications pertaining to applications of Nanotechnology to the management of Malignant Melanoma until August 2015. The terms used were melanoma, nanotechnology and nanoparticles for prospective and retrospective studies in the English Language to include animal studies. The search was limited to articles presenting or evaluating nanoparticles being investigated as both diagnostic but also treatment options for melanoma. Exclusion criteria were case reports, reviews and articles investigating nanotechnology use for other malignancies. The references of the included studies were screened to identify potential citations not captured by the MEDLINE search. Validation of search results was conducted by two separate reviewers (A.S and H.L.H.). Any discrepancy was reconciled by a third reviewer (A.P.). After the group of abstracts was agreed upon, these articles were reviewed in their entirety and selection of articles to include in this systematic review was based on each article meeting the criteria previously listed. An additional search of Trials underway globally was performed on www.clinicaltrials.gov and the results were incorporated in our study.

\section{Results}

\section{Nanotechnology in diagnostics}

Early diagnosis of malignant melanoma is key resulting in wide local excision and high survival rates [6]. The aim of using these nanoparticles is to achieve high specificity and sensitivity in the various diagnostic tests used, whilst reducing invasiveness and morbidity.

Quantum Dots [QD]: "Quantum Dots", are fluorescent nanoparticles composed of semiconductor nanocrystals that are being trialed in the detection of melanoma [13,14]. QDs are semiconductor crystals with optical and electrical properties that are relative to the energy released from excitons transitioning between energy levels. Their narrow field of emission and broad absorption spectra offer great photostability: at the near infrared region they emit at wavelengths ideal for deep tissue imaging thus making them useful in detection of cutaneous melanoma [15].

To improve targeting of cancer cells, various groups have studied the potential of Quantum Dots [QD] with molecules or antibodies specific to certain cancers in an aim to enhance their diagnostic properties and increase specificity. Already QDs have been conjugated with anti-HER2 monoclonal antibodies and have shown promising results in detecting breast tumours and promoting image guided surgery [15].

A research group lead by Zheng was able to detect melanoma in vitro by coupling Cadmium and Zinc [CdSe/ZnS] QD with CD146, an antigen that is over-expressed in melanoma cells [16]. The tumour cells were distinctly imaged separate from native melanocytes in a vitro setting.

Antibody-conjugated QD have been investigated as a means of imaging cells and labeling those undergoing apoptosis, separate from cells that are not. Antibodies generated against a human apoptotic peptide, calreticulin, conjugated to a specially coated QD has shown enormous potential in cancer detection and visualization [17]. In vivo use of QD has been practiced in mice to accurately localize human prostate cancer and hepatocellular cancer xenografts [18].

Despite their great optical and imaging potential, to date no animal studies or early phase clinical trials are published with QD used as an imaging modality for cancer. This is likely due to the toxicity, thrombogenicity and immunogenicity related to the heavy metal composition of QD [19-21].

In an attempt to overcome toxicity, many units have designed biologically compatible surface coating devices which unfortunately also raise concerns related to excretion and systemic sequestration. A novel device makes use of a polyhedral oligomeric silsesquioxane [POSS]-coated CdTe-cored QD using mercaptosuccinic acid [MSA] and D-cysteine as stabilizing agents [22]. The amphiphilic nature of this device renders it soluble in aqueous solutions and cell membranes thus enabling the use of lower QD concentrations to avoid their toxic sequelae [22].

Another limitation of QDs is their ability to penetrate cell membranes. New research in nanotechnology aims in bypassing this limitation by conjugating QD to Tat, a cell penetrating peptide sequence derived from human immunodeficiency virus [HIV]-1 [23]. As these Tat-conjugates are taken up by endocytosis and often entrapped with endosome lysosomes, extensive research, including the use of phthalocyanine photosensitisers is underway to improve bioavailability [23].

Cornell dots: Cornell Dots, another form of nanoparticles better known as C-Dots, have been used as probes in sentinel lymph node biopsy [24]. They are silica-based nanoparticles with a polyethylene 
glycol [PEG] shell which neutralizes their charge, preventing them from being scavenged by the liver, spleen and bone marrow. Their targeting peptide is the RGD that attaches to alpha 2 beta 3 integrin which is overexpressed in melanoma cells [25]. They are FDA approved and a group lead by Bradbury has made significant progress in the field of nanomedicine and melanoma, demonstrating in murine models that when these particles were injected in the presence of PET and optical imaging they were successful in detecting and localizing melanoma positive sentinel lymph nodes [24]. Theoretically C-Dots may serve a role in determining the tumour burden of positive nodes, as well as a molecular marker that can be used to monitor the response of ablative treatment.

As an exciting development C-dots are now in the early phases of clinical trials in the USA [26]. In the first human trial, technetium$99 \mathrm{~m}(99 \mathrm{mTc})$ sulphur colloid administered preoperatively and intraoperatively injected fluorescent cRGDY-PEG-Cy5.5-C dots are used for the identification of lymphatic spread to sentinel nodes. Intraoperative Near Infra Red (NIR) fluorescence imaging is performed using a hand-held fluorescence camera system, along with gamma counting for $99 \mathrm{mTc}$ sulfur colloid. Results are then histologically confirmed in resected tissue specimens [26].

Gold nanoparticles: Another important nanoparticle in this field is gold; particularly with it being considered toxically benign. Currently, melanoma targeted gold nanocages have been used in photoacoustic tomography with high specificity due to an enhancement in imaging resolution [27]. Gold nanoparticles directly labeled with the radioisotope indium-111 and conjugated again with RGD-based ligands have been used successfully in mice as radiotracers of melanoma [27]. Indium -111 is already approved for use in non-Hodgkins lymphoma [28]. These nanoparticles show great clinical promise in cancer imaging due to their high stability as labels, but also due to their low interference with the biological profile of melanoma [29,30] Unfortunately with regards to using gold to enhance CT imaging, the concentration of the gold nanoparticles required to deflect unwanted portions of the x-ray is currently impractically high [31].

Magnetic nanoparticles: In contrast to gold nanoparticles, magnetic nanoparticles [MNPs] have recently had great success in cancer diagnostics in clinical trials when used in conjunction with MRI [31]. In view of the positive early results of these trials, the use of MNPs has been extended to melanoma.

The MELAMAG trial forms a prospective multicenter feasibility non-randomised clinical trial comparing sentinel node biopsy using magnetic nanoparticles versus the standard technique. The basis of the new technique is to use an intradermal injection of magnetic nanoparticles [Sienna+] and a hand held magnetometer [SentiMag] to detect sentinel node[s] intraoperatively. Should this trial prove MNPs to be as effective as the standard technique, it has the potential to revolutionize imaging in melanoma by eliminating the use of radioactive materials and their associated hazards.

Superparamagnetic Iron Oxide [SPMIO]: This molecule travels via lymphatics to lymph nodes and acts as a negative contrast for T2 weighted MRI sequences with the metastatic deposits highlighted as white [32,33]. A study of the use of this particle in SLNB in breast cancer showed that SPMIO-MRI has the potential for an in vivo preoperative detection of metastatic lesions [32,33]. Similar success has been demonstrated in the use of super-paramagnetic carbodextrancoated iron oxide nanoparticles [34]. A prospective multicentre clinical trial comparing standard sentinel node biopsy using these magnetic nanoparticles versus standard use of patent blue dye and radioisotope in patients with breast cancer requiring SLNB is underway in the United Kingdom.

\section{Nanotechnology and melanoma treatment}

Drug delivery: Chemotherapy makes use of cytotoxic drugs to destroy highly proliferative cancer cells as well as normal cells that are in their division phase [35]. To date there is no evidence to show a survival benefit when using adjuvant chemotherapy in patients with metastatic melanoma and is consequently only used in the higher stages of disease [36-38].

The major disadvantage of all chemotherapeutic agents is cytotoxicity - they also kill normal cells leading to the well known side effects of reduced immunity, gastrointestinal inflammation and hair loss; these combined with low response rates are far from ideal [35]. Drug delivery methods can be used not only to reduce systemic side effects but to also improve pharmacokinetics in an attempt to make chemotherapy more user-friendly.

A study performed on an animal model using doxorubicin delivered via a fullerene nanoparticle shows similar efficacy to that of the free agent, but free from the undesirable toxic effects [39]. Additionally, this nanoparticle helped maintain a sustained drug release to the affected tumour [40]. Drugs encapsulated in delivery systems are able to remain in the blood stream longer, enabling sustained drug release, also providing more accurate tumour targeting [41,42].

In order to be effective drug delivery systems, nanoparticles are designed with multiple properties: high affinity to therapeutic agents, a stability within human serum, a propensity to be attracted to and bind on cancer cells specifically via ligands [43] to allow offloading of the named drug and safe degradation [44]. Some have the added advantage of delivering more than one drug at one time, hence allowing for combination therapy [45].

Drug delivery systems are classified as either active or passive targets [43]. Active systems involve specific interactions between the drug-loaded nanoparticles and tumours. This requires targeting nanoparticles with ligands specific to tumour cells. Such ligands include monoclonal antibodies, peptides, and nucleic acids [43]. Passive drug delivery systems rely on the permeation and retention effect whereby the leaky vessels and poor lymphatic drainage in tumours allows for increase drug accumulation [43]. To date, there are only four FDA approved nanoparticle-based cancer drug delivery systems but none of these is licensed for melanoma. Promising research is however under way.

Liposomes: Liposome based drug conjugates form a striking example of an effective nanoparticles based drug delivery system. They are artificial vesicles consisting of an aqueous core and outer phospholipid layer which can act as vessels for various drugs. Currently in the US and UK, liposome coated Doxorubicin [Doxil US, Myocet UK] is in use for ovarian cancer and myeloma. Unfortunately phase II trials of Doxil in melanoma therapy were discontinued due to ineffectiveness [46]. In vitro studies have been performed with docetaxel conjugated with carboxymethyl chitosan showing improved antitumour effect in B16 bearing melanoma mice [43]. Similarly a group led by Zhang et al. combined paclitaxel with polymeric micelles and found significant prevention in tumour growth, and increased survival time in subcutaneous and pulmonary B16-F10 melanoma mice [43]. 
PEG micelles: The most promising development for melanoma and liposomes is the Phase I trial underway in Japan involving NC6004, Cisplatin incorporating micelles. Cisplatin has previously been used in melanoma but is often withheld due to its neurotoxic and nephrotoxic side effects [46]. NC-6004 consists of a PEG, a complex of miscelles [similar to liposomes] and the drug Cisplatin. Animal work has been effective in demonstrating that in this form Cisplatin has greater accumulation in solid tumours but much less so in its distribution in normal tissue [47].

Albumin micelles: Polymeric nanoparticles particularly those made of albumin have shown promise as drug delivery systems for melanoma. Paclitaxel bound to an albumin derived nanoparticle, Abrexane, has been approved by the FDA since 2005 for the treatment of metastatic breast cancer [48]. Eight clinical trials have also been approved to investigate albumin bound paclitaxel for metastatic melanoma either alone or in conjunction with other drugs. To date the results of early phase clinical trials for chemotherapy naïve patients are promising.

Antibody-drug conjugates: Another nano-technique involved in drug delivery makes use of Antibody-Drug Conjugates (ADCs). ADCs are drug molecules conjugated to a single antibody used to target a molecule overexpressed on cancer cells. Usually these antibodies are conjugated with a drug that induces cell death. While this concept appears straightforward, only 2 FDA approved ADCs are available (Brentuximab vedotin and Trasruzumab emtansine) but none of these two trials are investigating their use in melanoma [49].

Studies have made use of this concept on murine models. Falvo et al. synthesized a novel antibody-drug conjugate incorporating ferritinbased nanoparticles. Monoclonal antibody $(\mathrm{mAb}) \mathrm{Ep} 1$ to the human melanoma-specific antigen CSPG4 were conjugated successfully to a single ferritin cage encapsulating cisplatin molecules (HFt-Pt-Ep1) causing tumour cell death [49].

Various nanoparticles loaded with different combinations of drugs targeting melanoma are continuously being developed indicating great hope for the future of nano-drug delivery platforms for advanced melanoma. These are summarized in Table 1.

Molecular targeting, gene silencing and cell targeting: Emerging evidence links the development of melanoma and its metastasis to mutations in genes encoding CDK4, MCIR, and CDKAN2A, somatic mutations in pro-oncogenes B-RAF, N-RAS and KIT as well as tumour suppressor genes PTEN, P53 and CDKN2A. Recent advances in understanding these key mutations have opened the door to the development of new therapeutic treatments. These technologies either target melanoma specific mutations and pathways, or cell surface markers on the tumour cells in an attempt to improve drug delivery, allowing for gene silencing or the design of vaccines to target tumours.

Nanoparticles and gene silencing: Gene silencing therapy involves the use of small interfering RNA (siRNA), plasmid DNA or antisense oligonucleotides to target certain molecular chains inhibiting gene expression [50,51]. Of these techniques, siRNA's have shown most promise. siRNAS are double stranded RNA molecules that have the capacity to interfere with the translation of specific mRNAs based on their sequence. They interact with an Argonaute (a catalytic portion of an RNA-induced silencing complex) which unwinds the molecule and also degrades its sense strands to prevent the process of translation. The antisense strand then binds onto the complementary mRNA of the desired gene sequence targeting it to further be degraded by the Argonaute. This process of gene silencing makes use of a process

\section{known as RNA interference [51].}

As with the previously described drug therapies, siRNAs are not without their limitations. The most significant problem is an inability to deliver sufficient siRNA into the cytoplasm of target cells, while other issues include accidental silencing of non-intended, non-target mRNA and inflammation [52].

Nanoparticles have been developed which are shown to carry and protect the siRNA, specifically delivering it to their target cells and together with their contained target, the siRNA can be efficiently taken up into the cell. Nanolipids and gold nanoparticles are thought to be the most promising molecules for clinical application [53].

Undoubtedly, the most researched signaling cascade in melanoma is the MAPK-ERK pathway (mitogen-activated protein kinaseextracellular-related kinase) [54]. siRNA inhibitors have been trialed in an aim to silence mutations in this pathway that are linked to the development of melanoma. siRNA lysosomal nanoparticles have already been used to effectively silence the STAT3 gene (signal transducer and activator of transcription 3) in B16 melanoma cells; reducing melanoma cell viability to $16 \%$ after only 3 doses [55].

The first human clinical trial in this field involved CALAA-01, an siRNA molecule that makes use of a cyclodextrin- polymer based nanoparticle. This trial demonstrated that siRNA administered systemically to humans can produce a specific gene inhibition by means of RNA interference [56].

Anti-melanoma vaccines and cell targeting: Targeting of melanoma cells with nanoparticles is another desirable treatment modality. Melanoma specific cell surface markers have been identified and expressed to allow successful nanoparticle -targeting. In theory, such target molecules must be expressed at very high levels on melanoma cells but at very low or ideally negligible levels on normal cells. This would allow specific drug delivery systems to operate but also anti-melanoma vaccines making use of gene silencing techniques.

Phase 1 trials using siRNA and nanoparticles confirmed the safety and efficacy of an anti-melanoma vaccine [57]. An siRNA- nanoparticle combination has been used against BRAF and Akt3 effectively inhibiting cutaneous melanocytic lesion development [58]. Similarly an antisense oligonucleotide against an anti-apoptotic protein $\mathrm{Bcl}-2$, Oblimersen, showed a decrease in melanoma growth in vitro and in vivo [59].

Used as a combination therapy in a Phase 1 trial with 2 other albumin coated chemotherapeutic agents, this gene silencing vaccine has proven to more effective against advanced stage melanoma [60]. Basu et al. showed that nanoparticle-mediated targeting of MAPK signaling inhibits proliferation and induces apoptosis of melanoma cells, also enhancing the effect of chemotherapy on these cells [61].

MC1R [melanocortin-1 receptor] which is expressed on melanocytes but at a much higher concentration on melanoma cells is one such ligands that nanoparticles can use to permeate cell targeting [62]. Lu et al. have used a murine model to successfully conjugate gold nanospheres to the alpha-melanocyte-stimulating hormone (MSH) analog, a potent agonist of MC1R. The targeted melanoma cells can then be eliminated via photothermal ablation, a concept which will be discussed further in this review [63].

Immunotherapy: Cancer immunotherapy aims at improving the immune system of a patient in order to increase the clearance of cancer cells from the body. This can be achieved via cell-mediated, 
Citation: Lloyd-Hughes H, Shiatis AE, Pabari A, Mosahebi A, Seifalian A (2015) Current and Future Nanotechnology Applications in the Management of Melanoma: A Review. J Nanomed Nanotechnol 6: 334. doi:10.4172/2157-7439.1000334

Page 5 of 12

\begin{tabular}{|c|c|c|c|c|c|c|c|}
\hline NANO-technology & Study ID & Study Title & Phase & Drug & Study design & Study arms & Condition \\
\hline Immunotherapy & NCT02054520 & $\begin{array}{l}\text { Immunotherapy Study for } \\
\text { Patients With Stage IV } \\
\text { Melanoma }\end{array}$ & IIB & $\begin{array}{l}\text { HyperAcute } ®- \\
\text { Melanoma (HAM) } \\
\text { Immunotherapy }\end{array}$ & $\begin{array}{l}\text { Allocation: Randomized } \\
\text { Endpoint Classification: } \\
\text { Safety/Efficacy Study } \\
\text { Intervention Model: Single } \\
\text { Group Assignment } \\
\text { Masking: Open Label } \\
\text { Primary Purpose: } \\
\text { Treatment }\end{array}$ & $\begin{array}{l}\text { Experimental: } \\
\text { HyperAcute } \AA- \\
\text { Melanoma (HAM) } \\
\text { Immunotherapy + } \\
\text { Ipilimumab } \\
\text { Active Comparator: } \\
\text { Ipilimumab Alone }\end{array}$ & Stage 4 melanoma \\
\hline $\begin{array}{l}\text { Polymeric } \\
\text { Nanoparticles }\end{array}$ & NCT02158520 & $\begin{array}{l}\text { Paclitaxel Albumin- } \\
\text { Stabilized Nanoparticle } \\
\text { Formulation and } \\
\text { Bevacizumab or } \\
\text { Ipilimumab as First-Line } \\
\text { Therapy in Treating } \\
\text { Patients With Stage IV } \\
\text { Melanoma That Cannot } \\
\text { Be Removed By Surgery }\end{array}$ & II & $\begin{array}{l}\text { paclitaxel albumin- } \\
\text { stabilized nanoparticle } \\
\text { formulation }\end{array}$ & $\begin{array}{l}\text { Allocation: Randomized } \\
\text { Endpoint Classification: } \\
\text { Efficacy Study } \\
\text { Intervention Model: } \\
\text { Crossover Assignment } \\
\text { Masking: Open Label } \\
\text { Primary Purpose: } \\
\text { Treatment }\end{array}$ & $\begin{array}{l}\text { Experimental: Arm A } \\
\text { (nab-paclitaxel and } \\
\text { bevacizumab) } \\
\text { Experimental: Arm B } \\
\text { (ipilimumab) }\end{array}$ & $\begin{array}{l}\cdot \quad \text { Stage IIIA } \\
\text { Melanoma } \\
\text { - Stage IIIB } \\
\text { Melanoma } \\
\cdot \quad \text { Stage IIIC } \\
\text { Melanoma } \\
\text { Stage IV } \\
\text { Melanoma }\end{array}$ \\
\hline $\begin{array}{l}\text { Polymeric } \\
\text { Nanoparticles }\end{array}$ & NCT00626405 & $\begin{array}{l}\text { Bevacizumab and } \\
\text { Temozolomide or } \\
\text { Bevacizumab and } \\
\text { Paclitaxel Albumin- } \\
\text { Stabilized Nanoparticle } \\
\text { Formulation and } \\
\text { Carboplatin in Treating } \\
\text { Patients With Stage IV } \\
\text { Malignant Melanoma } \\
\text { That Cannot Be } \\
\text { Removed by Surgery }\end{array}$ & II & $\begin{array}{l}\text { Biological: } \\
\text { bevacizumab } \\
\text { Drug: carboplatin } \\
\text { Drug: paclitaxel } \\
\text { albumin-stabilized } \\
\text { nanoparticle } \\
\text { formulation } \\
\text { Drug: temozolomide }\end{array}$ & $\begin{array}{l}\text { Allocation: Randomized } \\
\text { Primary Purpose: } \\
\text { Treatmen }\end{array}$ & $\begin{array}{l}\text { Experimental: Arm I } \\
\text { Interventions: } \\
\text { - Biological: } \\
\text { bevacizumab } \\
\text { Drug: temozolomide } \\
\text { Experimental: Arm II } \\
\text { Interventions: } \\
\text { - Biological: } \\
\text { bevacizumab } \\
\text { - Drug: carboplatin } \\
\text { Drug: paclitaxel } \\
\text { albumin-stabilized } \\
\text { nanoparticle formulation }\end{array}$ & MELANOMA \\
\hline siRNA & NCT00689065 & $\begin{array}{l}\text { A Phase I, Dose- } \\
\text { Escalating Study of the } \\
\text { Safety of Intravenous } \\
\text { CALAA- } 01 \text { in Adults With } \\
\text { Solid Tumors Refractory } \\
\text { to Standard-of-Care } \\
\text { Therapies }\end{array}$ & I & $\begin{array}{l}\text { CALAA-01: a small } \\
\text { interfering RNA } \\
\text { (siRNA). This siRNA } \\
\text { inhibits tumor growth } \\
\text { via RNA interference } \\
\text { to reduce expression } \\
\text { of the M2 subunit } \\
\text { of ribonucleotide } \\
\text { reductase (R2). The } \\
\text { CALAA-01 siRNA } \\
\text { is protected from } \\
\text { nuclease degradation } \\
\text { within a stabilized } \\
\text { nanoparticle targeted } \\
\text { to tumor cells. }\end{array}$ & $\begin{array}{l}\text { Endpoint Classification: } \\
\text { Safety Study } \\
\text { Intervention Model: Single } \\
\text { Group Assignment } \\
\text { Masking: Open Label } \\
\text { Primary Purpose: } \\
\text { Treatmen }\end{array}$ & $\begin{array}{l}\text { Experimental: } \\
\text { CALAA-01 } \\
\text { Intervention: Drug: } \\
\text { CALAA-01 }\end{array}$ & Solid Tumours \\
\hline $\begin{array}{l}\text { Polymeric } \\
\text { Nanoparticles }\end{array}$ & NCT00404235 & $\begin{array}{l}\text { Carboplatin and ABI-007 } \\
\text { in Treating Patients With } \\
\text { Stage IV Melanoma That } \\
\text { Cannot Be Removed By } \\
\text { Surgery }\end{array}$ & ii & $\begin{array}{l}\text { - Drug: carboplatin } \\
\text { - Drug: paclitaxel } \\
\text { albumin-stabilized } \\
\text { nanoparticle } \\
\text { formulation }\end{array}$ & $\begin{array}{l}\text { Masking: Open Label } \\
\text { Primary Purpose: } \\
\text { Treatment }\end{array}$ & $\begin{array}{l}\text { This phase II trial is } \\
\text { studying the side effects } \\
\text { and how well giving } \\
\text { carboplatin together } \\
\text { with ABI- } 007 \text { works in } \\
\text { treating patients with } \\
\text { stage IV melanoma that } \\
\text { cannot be removed by } \\
\text { surgery. }\end{array}$ & Melanoma \\
\hline Quantum Dots & NCT02106598 & $\begin{array}{l}\text { Targeted Silica } \\
\text { Nanoparticles for Image- } \\
\text { Guided Intraoperative } \\
\text { Sentinel Lymph Node } \\
\text { Mapping in Head } \\
\text { and Neck Melanoma, } \\
\text { Prostate and Cervical/ } \\
\text { Uterine Cancer Patients }\end{array}$ & 0 & $\begin{array}{l}\text { fluorescent cRGDY- } \\
\text { PEG-Cy5.5-C dots }\end{array}$ & $\begin{array}{l}\text { Endpoint Classification: } \\
\text { Efficacy Study } \\
\text { Intervention Model: Single } \\
\text { Group Assignment } \\
\text { Masking: Open Label } \\
\text { Primary Purpose: } \\
\text { Diagnostic }\end{array}$ & $\begin{array}{l}\text { Melanoma patients } \\
\text { will be injected with a } \\
\text { radioactive dye around } \\
\text { the tumor site, and } \\
\text { images will be acquired } \\
\text { about } 2 \text { hours the } \\
\text { location of the later } \\
\text { using a device to image } \\
\text { the dye. }\end{array}$ & \\
\hline
\end{tabular}


Citation: Lloyd-Hughes H, Shiatis AE, Pabari A, Mosahebi A, Seifalian A (2015) Current and Future Nanotechnology Applications in the Management of Melanoma: A Review. J Nanomed Nanotechnol 6: 334. doi:10.4172/2157-7439.1000334

Page 6 of 12

\begin{tabular}{|c|c|c|c|c|c|c|c|}
\hline $\begin{array}{l}\text { ADC (antibody drug } \\
\text { conjugates) }\end{array}$ & NCT02129075 & $\begin{array}{l}\text { CDX-1401 and Poly- } \\
\text { ICLC Vaccine Therapy } \\
\text { With or Without CDX- } \\
301 \text { in Treating Patients } \\
\text { With Stage IIB-IV } \\
\text { Melanoma }\end{array}$ & ii & & $\begin{array}{l}\text { Allocation: Randomized } \\
\text { Endpoint Classification: } \\
\text { Efficacy Study } \\
\text { Intervention Model: } \\
\text { Parallel Assignment } \\
\text { Masking: Open Label } \\
\text { Primary Purpose: } \\
\text { Treatment }\end{array}$ & $\begin{array}{l}\text { This randomized phase } \\
\text { II trial studies how well } \\
\text { DEC-205/NY-ESO-1 } \\
\text { fusion protein CDX- } \\
1401 \text { (CDX-1401) and } \\
\text { neoantigen-based } \\
\text { melanoma-poly-ICLC } \\
\text { vaccine (poly-ICLC) } \\
\text { vaccine therapy work } \\
\text { when given with or } \\
\text { without recombinant } \\
\text { flt3 ligand (CDX-301) } \\
\text { in treating patients with } \\
\text { stage IIB-IV melanoma }\end{array}$ & \\
\hline Immunotherapy & NCT01814046 & $\begin{array}{l}\text { Adoptive T Cell Therapy } \\
\text { for Metastatic Ocular } \\
\text { Melanoma }\end{array}$ & II & Drug: Aldesleukin & $\begin{array}{l}\text { Allocation: Non- } \\
\text { Randomized } \\
\text { Endpoint Classification: } \\
\text { Safety/Efficacy Study } \\
\text { Intervention Model: Single } \\
\text { Group Assignment } \\
\text { Masking: Open Label } \\
\text { Primary Purpose: } \\
\text { Treatment }\end{array}$ & $\begin{array}{l}\text { Participants will receive } \\
\text { an infusion of their } \\
\text { collected white blood } \\
\text { cells. They will also } \\
\text { receive aldesleukin for } \\
\text { up to } 5 \text { days to boost } \\
\text { the immune system's } \\
\text { response to the white } \\
\text { blood cells. }\end{array}$ & $\begin{array}{l}\text { - Metastatic } \\
\text { Ocular Melanoma } \\
\text { Metastatic Uveal } \\
\text { Melanoma }\end{array}$ \\
\hline Immunotherapy & NCT01863108 & $\begin{array}{l}\text { Safety Study of a } \\
\text { Dendritic Cell-based } \\
\text { Cancer Vaccine in } \\
\text { Melanoma }\end{array}$ & i & $\begin{array}{l}\text { GeniusVac-Mel4:a } \\
\text { drug product } \\
\text { composed of an } \\
\text { irradiated allogeneic } \\
\text { plasmacytoid } \\
\text { dendritic cell (PDC) } \\
\text { line loaded with } 4 \\
\text { melanoma peptides } \\
\text { derived from Melan-A, } \\
\text { gp100, Tyrosinase or } \\
\text { Mage-A3 }\end{array}$ & $\begin{array}{l}\text { Endpoint Classification: } \\
\text { Safety Study } \\
\text { Intervention Model: Single } \\
\text { Group Assignment } \\
\text { Masking: Open Label } \\
\text { Primary Purpose: } \\
\text { Treatment }\end{array}$ & $\begin{array}{l}\text { Experimental: } \\
\text { GeniusVac-Mel4 } \\
\text { Sub-cutaneous } \\
\text { injections of GeniusVac- } \\
\text { Mel4 in patients with } \\
\text { melanoma. } \\
\text { Intervention: Biological: } \\
\text { GeniusVac-Mel4 }\end{array}$ & melanoma \\
\hline Quantum Dots & NCT01266096 & $\begin{array}{l}\text { PET Imaging of Patients } \\
\text { With Melanoma and } \\
\text { Malignant Brain Tumors } \\
\text { Using an 124I-labeled } \\
\text { cRGDY Silica } \\
\text { Nanomolecular Particle } \\
\text { Tracer: A Microdosing } \\
\text { Study }\end{array}$ & & $\begin{array}{l}\text { PET scan with } \\
\text { 124I-cRGDY-PEG- } \\
\text { dots }\end{array}$ & $\begin{array}{l}\text { Allocation: Non- } \\
\text { Randomized } \\
\text { Endpoint Classification: } \\
\text { Safety/Efficacy Study } \\
\text { Intervention Model: Single } \\
\text { Group Assignment } \\
\text { Masking: Open Label } \\
\text { Primary Purpose: } \\
\text { Diagnostic }\end{array}$ & & $\begin{array}{l}\text { - Newly } \\
\text { Diagnosed } \\
\text { or Recurrent } \\
\text { Metastatic } \\
\text { Melanoma Patients } \\
\text { Malignant Brain } \\
\text { Tumors }\end{array}$ \\
\hline siRNA & NCT01941927 & $\begin{array}{l}\text { Trametinib With } \\
\text { GSK2141795 in BRAF } \\
\text { Wild-type Melanoma }\end{array}$ & li & $\begin{array}{l}\text { - Drug: Trametinib } \\
\text { (GSK1120212) } \\
\text { Drug: GSK2141795 }\end{array}$ & $\begin{array}{l}\text { Endpoint Classification: } \\
\text { Efficacy Study } \\
\text { Intervention Model: Single } \\
\text { Group Assignment } \\
\text { Masking: Open Label } \\
\text { Primary Purpose: } \\
\text { Treatment }\end{array}$ & & \\
\hline Tumour targetting & NCT02236546 & $\begin{array}{l}\text { FDG-PET/CT as a } \\
\text { Biomarker for Treatment } \\
\text { Response in Advanced } \\
\text { Melanoma }\end{array}$ & & $\begin{array}{l}18 \mathrm{~F}] \\
\text { fluorodeoxyglucose } \\
\text { (FDG) }\end{array}$ & $\begin{array}{l}\text { Endpoint Classification: } \\
\text { Efficacy Study } \\
\text { Intervention Model: Single } \\
\text { Group Assignment } \\
\text { Masking: Open Label } \\
\text { Primary Purpose: } \\
\text { Diagnostic }\end{array}$ & $\begin{array}{l}\text { Patients undergo [18F] } \\
\text { fluorodeoxyglucose } \\
\text { (FDG) positron } \\
\text { emission tomography } \\
\text { (PET)/computed } \\
\text { tomography (CT) up } \\
\text { to } 2 \text { weeks prior to } \\
\text { first dose of therapy, } \\
\text { after completion of the } \\
\text { first treatment course } \\
\text { (day 21), and after } \\
\text { completion of the fourth } \\
\text { treatment course (day } \\
84 \text { ). }\end{array}$ & $\begin{array}{l}\text { - Recurrent } \\
\text { Melanoma } \\
\text { - Stage IIIA } \\
\text { Melanoma } \\
\text { - Stage IIIB } \\
\text { Melanoma } \\
\text { - Stage IIIC } \\
\text { Melanoma } \\
\text { Stage IV } \\
\text { Melanoma }\end{array}$ \\
\hline Imaging & NCT02106598 & $\begin{array}{l}\text { Targeted Silica } \\
\text { Nanoparticles for Image- } \\
\text { Guided Intraoperative } \\
\text { Sentinel Lymph Node } \\
\text { Mapping in Head } \\
\text { and Neck Melanoma, } \\
\text { Prostate and Cervical/ } \\
\text { Uterine Cancer Patients }\end{array}$ & 0 & $\begin{array}{l}\text { fluorescent cRGDY- } \\
\text { PEG-Cy5.5-C dots }\end{array}$ & $\begin{array}{l}\text { Endpoint Classification: } \\
\text { Efficacy Study } \\
\text { Intervention Model: Single } \\
\text { Group Assignment } \\
\text { Masking: Open Label } \\
\text { Primary Purpose: } \\
\text { Diagnostic }\end{array}$ & $\begin{array}{l}\text { Melanoma patients } \\
\text { will be injected with a } \\
\text { radioactive dye around } \\
\text { the tumor site, and } \\
\text { images will be acquired } \\
\text { about } 2 \text { hours the } \\
\text { location of the later using } \\
\text { a device to image the } \\
\text { dye. }\end{array}$ & $\begin{array}{l}\text { - Head and Neck } \\
\text { Cancer } \\
\text { - Melanoma } \\
\text { - Prostate } \\
\text { Cancer } \\
\text { - Cervical Cancer } \\
\text { Uterine Cancer }\end{array}$ \\
\hline
\end{tabular}


Citation: Lloyd-Hughes H, Shiatis AE, Pabari A, Mosahebi A, Seifalian A (2015) Current and Future Nanotechnology Applications in the Management of Melanoma: A Review. J Nanomed Nanotechnol 6: 334. doi:10.4172/2157-7439.1000334

Page 7 of 12

\begin{tabular}{|c|c|c|c|c|c|c|c|}
\hline Imaging & & $\begin{array}{l}\text { Sentinel Node Biopsy } \\
\text { using Magnetic } \\
\text { Nanoparticles for } \\
\text { melanoma }\end{array}$ & & Sienna+ & $\begin{array}{l}\text { Detection rate with either } \\
\text { the standard (blue dye } \\
\text { and isotope) or the new } \\
\text { technique (magnetic) } \\
\text { Timepoint(s): The } \\
\text { proportion of sentinel } \\
\text { nodes detected (detection } \\
\text { rate) with either the } \\
\text { standard or the new } \\
\text { magnetic technique }\end{array}$ & $\begin{array}{l}\text { Non-randomised; } \\
\text { Interventional; Design } \\
\text { type: Diagnosis }\end{array}$ & melanoma \\
\hline siRNA & NCT00672542 & $\begin{array}{l}\text { Immunotherapy of } \\
\text { Melanoma With Tumor } \\
\text { Antigen RNA and } \\
\text { Small Inhibitory RNA } \\
\text { Transfected Autologous } \\
\text { Dendritic Cells }\end{array}$ & 1 & $\begin{array}{l}\text { Proteasome siRNA } \\
\text { and tumor antigen } \\
\text { RNA-transfected } \\
\text { dendritic cells }\end{array}$ & $\begin{array}{l}\text { Allocation: Non- } \\
\text { Randomized } \\
\text { Endpoint Classification: } \\
\text { Safety Study } \\
\text { Intervention Model: Single } \\
\text { Group Assignment } \\
\text { Masking: Open Label } \\
\text { Primary Purpose: } \\
\text { Treatment } \\
\\
\end{array}$ & $\begin{array}{l}\text { - Experimental: A } \\
\text { siRNA loaded } \\
\text { dendritic cells derived } \\
\text { from untreated } \\
\text { monocytes Intervention: } \\
\text { Biological: Proteasome } \\
\text { siRNA and tumor } \\
\text { antigen RNA- } \\
\text { transfected dendritic } \\
\text { cells } \\
\text { - Experimental: B } \\
\text { Vaccination with } \\
\text { melanoma tumor } \\
\text { associated antigen } \\
\text { RNA loaded dendritic } \\
\text { cells derived from } \\
\text { monocytes transfected } \\
\text { with control siRNA } \\
\text { Intervention: Biological: } \\
\text { Proteasome siRNA and } \\
\text { tumor antigen RNA- } \\
\text { transfected dendritic } \\
\text { cells } \\
\text { Experimental: C } \\
\text { Vaccination with } \\
\text { melanoma tumor } \\
\text { associated antigen } \\
\text { RNA loaded dendritic } \\
\text { cells derived from } \\
\text { monocytes transfected } \\
\text { with siRNA targeting } \\
\text { the three inducible } \\
\text { immunoproteasome } \\
\text { subunits Intervention: } \\
\text { Biological: Proteasome } \\
\text { siRNA and tumor } \\
\text { antigen RNA- } \\
\text { transfected dendritic } \\
\text { cells } \\
\end{array}$ & $\begin{array}{l}\text { Metastatic } \\
\text { Melanoma with } \\
\text { Absence of CNS } \\
\text { Metastases }\end{array}$ \\
\hline siRNA & NCT02166255 & $\begin{array}{l}\text { APN401 in Treating } \\
\text { Patients With Melanoma, } \\
\text { Kidney Cancer, } \\
\text { Pancreatic Cancer, or } \\
\text { Other Solid Tumors That } \\
\text { Are Metastatic or Cannot } \\
\text { Be Removed By Surgery }\end{array}$ & I & $\begin{array}{l}\text { siRNA-transfected } \\
\text { peripheral blood } \\
\text { mononuclear cells } \\
\text { APN401 }\end{array}$ & $\begin{array}{l}\text { Endpoint Classification: } \\
\text { Safety/Efficacy Study } \\
\text { Intervention Model: Single } \\
\text { Group Assignment } \\
\text { Masking: Open Label } \\
\text { Primary Purpose: } \\
\text { Treatment }\end{array}$ & $\begin{array}{l}\text { Experimental: } \\
\text { Treatment (APN401) }\end{array}$ & $\begin{array}{l}\text { - } \text { Recurrent } \\
\text { Melanoma } \\
\text { - } \quad \text { Recurrent } \\
\text { Pancreatic Cancer } \\
\text { - } \quad \text { Recurrent } \\
\text { Renal Cell Cancer } \\
\text { - Stage III } \\
\text { Pancreatic Cancer } \\
\text { - Stage III Renal } \\
\text { Cell Cancer } \\
\text { - Stage IIIA } \\
\text { Melanoma } \\
\text { - Stage IIIB } \\
\text { Melanoma } \\
\text { - Stage IIIC } \\
\text { Melanoma } \\
\text { - Stage IV } \\
\text { Melanoma } \\
\text { - Stage IV } \\
\text { Pancreatic Cancer } \\
\text { - Stage IV Renal } \\
\text { Cell Cancer } \\
\text { Unspecified Adult } \\
\text { Solid Tumor, } \\
\text { Protocol Specific }\end{array}$ \\
\hline
\end{tabular}

Table 1: Current clinical trials making use of nano-technology in melanoma (as per www.clinicaltrials.gov) (101). 
antibody and cytokine therapies. These agents target cancer antigens - molecules similar to cell surface markers that cancer cells specifically express; nominally proteins but also other molecules such as carbohydrates. Immunotherapy aids the body in clearing cells damaged by chemotherapy and targeted therapy to improve clearance and resolution $[64,65]$.

Antibody therapy: Antibody therapy is the most successful form of immunotherapy, but currently there is no cell-based therapy approved for melanoma. The phase 3 trials previously performed have had disappointing results but research is still ongoing and 19 trials are registered to date. Current research is focused on Ipilimumab a monoclonal antibody that blocks CTLA- 4 found on the surface of T-cells. Designing a nanoparticle that carries and delivers this monoclonal antibody to $\mathrm{T}$-cells may be the next stage in improving cytotoxic responses, decreasing side effects, inflammation and even further prolonging survival from advanced melanoma.

Stephan et al. [66] have designed maleimide-functionalized nanoparticles that are able to bind to free thiol groups on T-cell membrane proteins. This is anefficient way of delivering compounds onto the $\mathrm{T}$ cell synapse, and promoting $\mathrm{T}$-cell expansion at the tumour site. Another study conducted in Japan found that N-propionyl cysteaminyl phenol-maleimide-dextran [NPCMD] stimulated CD14 ${ }^{+}$monocytes and THP-1 cells to secrete TNFa, IL-6 and IL-8, but not IL-10 or IL-12. The immunopotentiating effect of NPCMD mediated by TLR4 and NLRP3 inflammasome activation could be used as method of potentiating an effective adaptive immune response against melanoma [66].

Another form of immunotherapy is mediated via the action of IL2 and INFa, which are immunomodulators that stimulate the immune system to attack abnormal cells found in cancers like melanoma. Such form of immunotherapy, however, has a wide range of side effects. Yao et al. designed a polyethylenimine based nanoparticles which was linked to folate conjugated beta-cycodextrin and interleukin-2 plasmid, in an aim to reduce the toxic effects of these immunomodulators. Murine studies of this agent show a regression of melanoma growth and increased survival [67].

Similarly, Cejudo-Guillen et al. [68] successfully used a nanoporous miniature device for local delivery of INFa achieving a constant slow release and hence avoiding severe side effects.

Photodynamic therapy: Photodynamic therapy (PDT) has recently emerged as another therapeutic option in treating cancer. It makes use of cytotoxic oxygen-based molecules in order to promote cell death. It uses a photosensitizer, a chemical activated by light of a certain wavelength, to generate cytotoxic oxygen based molecular species such as oxides $\left(\mathrm{O}_{2}\right)$, superoxides $\left(\mathrm{O}_{2}^{-}\right)$and peroxides $(\mathrm{OH})$ [69]. These reactive molecules damage subcellular organelles and plasma membranes of cells resulting in their death.

The role of nanotechnology is to improve PDT by making it more targeted and efficient, using nanoparticles that are either active or passive. Passive PDT nanoparticles are carriers of photosensitizers only. Active PDT nanoparticles can themselves generate reactive molecules without the need for a photosensitizer [69].

Navarro et al. designed nanocarriers composed of biocompatible polymers grafted on gold nanospheres. When labeled with a fluorescent photosensitizer, they can trigger cell death in melanoma enhancing the activity of passive PDT [70]. Vijayaraghavan et al. also showed that gold nanoshells can absorb near-infrared light, emit fluorescence, form oxygen free radicals and induce nanomaterial mediated photodynamic therapy [NmPDT] leading to complete destruction of solid melanoma tumors in mice [71]. Samia et al. using semiconductor Quantum dots was the first to introduce the concept of nanoparticles as active generators of singlet oxygen molecules and much work is now evolving in this field although this is yet to be taken to clinical trials phase [72].

Photothermal therapy: Photothermal therapy [PTT] uses photothermal agents to achieve selective and controlled heating of target cancer cells, confining thermal damage to the tumour only. Gold nanoparticle and carbon nanotubes have strong absorption in the nearinfra red regions of the electromagnetic spectrum making them ideal for in vivo PTT. The use of these nanoparticles has lead to lower laser energy requirements allowing for only local cellular destruction and death.

Primarily, the photosensitizer nanoparticles must accumulate within the target tumour and this can be achieved by functionalizing the nanoparticles with specific tumour targeting molecules. Jung et al. have synthesized a nanographene oxide-hyaluronic acid conjugate (NGOHA) for photothermal ablation of melanoma [73]. This was delivered transdermally to the tumour in mice skin and was then irradiated with a near-infrared laser (NIR). Laser irradiation resulted in the tumour being ablated completely and no recurrence was seen. In a similar study, Chu et al. injected fluorescent quantum dots - CdTe(710) QDs coated with silica and showed that the growth of murine melanoma tumours was significantly inhibited after laser irradiation, with eventual disappearance of the tumour [74].

The positive results of PTT either alone or in conjunction with other treatments shows great promise for the future. Although no study has been translated into a clinical trial for melanoma it must only be a matter of time, as PTT making use of AuroShell (gold metal shell and silica cover) has entered human trials in the management of neck and lung cancer.

\section{Theranostics}

Theranostics describes the ability of substances such as nanoparticles to be used for simultaneous diagnosis and treatment. The ideal theranostic nanoparticle would be one that could diagnose melanoma, deliver a targeted therapy and then assay the response of the melanoma to this therapy. As biochemical techniques have improved dramatically, it is now possible to create nanoparticles that are multidimensional, having both hydrophilic and hydrophobic facets allowing them, for example, to carry a hydrophilic contrast and hydrophobic drug.

Theoretically, the combinations are limitless. Multimodal nanoparticles have been designed to have a superparamagnetic core to allow imaging with MRI and a gold shell to facilitate PTT. [75] Similarly silica -coated gold nanorods have strong attenuation for XRay and CT imaging and can also be used for PTT. SPIONs used in MRI can be loaded with a chemotherapeutic drug or gene delivery carrier and then tracked with MRI. Gold nanoparticles can be combined with photosensitizers for dual modality treatment - PDT and PTT.

$\mathrm{Wu}$ et al. developed hybrid nanogels by coating a Ag-Au bimetallic NP core with a thermo-responsive nonlinear poly (ethylene glycol) (PEG)-based hydrogel as shell [76]. The Ag-Au NP core induced fluorescence and was used in mice for imaging and identifying melanoma B16F10 cells. The reversible thermo-responsive volume phase transition of the nonlinear PEG-based gel shell was able to modify the physicochemical environment of the $\mathrm{Ag}-\mathrm{Au} \mathrm{NP}$ core providing a 
Citation: Lloyd-Hughes H, Shiatis AE, Pabari A, Mosahebi A, Seifalian A (2015) Current and Future Nanotechnology Applications in the Management of Melanoma: A Review. J Nanomed Nanotechnol 6: 334. doi:10.4172/2157-7439.1000334

Page 9 of 12

\begin{tabular}{|c|c|c|c|c|}
\hline Nanoparticle & Description & Clinical Use & Side Effects & Studies \\
\hline \multicolumn{5}{|c|}{ Nanoparticles Used in Diagnosis of Melanoma } \\
\hline Quantum Dots $[20,21,22]$ & $\begin{array}{l}\text { Cadmium and Zinc (CdSe/ZnS) QD } \\
\text { with CD146, an antigen that is over- } \\
\text { expressed in melanoma cells }\end{array}$ & $\begin{array}{l}\text { Targetting of melanoma cells for } \\
\text { diagnostic and imaging purposes. }\end{array}$ & $\begin{array}{l}\text { Thrombogenicity and } \\
\text { immunogenicity }\end{array}$ & $\mathrm{n} / \mathrm{a}$ \\
\hline Quantum Dots [28] & $\begin{array}{l}\text { Polyhedral oligomeric silsesquioxane } \\
\text { (POSS)-coated CdTe-cored QD using } \\
\text { mercaptosuccinic acid (MSA) and } \\
\text { D-cysteine as stabilising agents }\end{array}$ & $\begin{array}{l}\text { The amphiphilic nature of this device } \\
\text { renders it soluble in aqueous solutions } \\
\text { and cell membranes enabling the use } \\
\text { of lower QD concentrations hence } \\
\text { avoiding toxicity. }\end{array}$ & n/a & $\mathrm{n} / \mathrm{a}$ \\
\hline \multirow[t]{3}{*}{ C- Dots $[30,31]$} & \multirow{3}{*}{$\begin{array}{l}\text { Silica Based nanoparticles with poly- } \\
\text { ethylene glycol (PEG) shell }\end{array}$} & \multirow{3}{*}{$\begin{array}{l}\text { Enhancement of Sentinel Lymph Node } \\
\text { Biopsies (SLNB) }\end{array}$} & \multirow{3}{*}{ FDA approved } & Clinical Trial \\
\hline & & & & IND approved \\
\hline & & & & Phase 0 clinical trial (since 2011) \\
\hline \multirow[t]{2}{*}{ C Dots [32] } & \multirow{2}{*}{$\begin{array}{l}\text { technetium-99m }(99 \mathrm{mTc}) \text { sulphur } \\
\text { colloid and fluorescent cRGDY-PEG- } \\
\text { Cy5.5-C dots }\end{array}$} & \multirow[t]{2}{*}{$\begin{array}{l}\text { Tumour localisation and detection } \\
\text { using fluorescence camera. }\end{array}$} & \multirow[t]{2}{*}{ In trial } & Clinical Trial stage Phase $O$ \\
\hline & & & & NCT02106598 \\
\hline Gold Nanorods [33] & $\begin{array}{l}\text { gold nanorods conjugated with Arg-Gly- } \\
\text { Asp peptides (RGD-GNRs) }\end{array}$ & $\begin{array}{l}\text { Enhance the response of melanoma } \\
\text { cells to } 6 \mathrm{mV} \text { radiation. }\end{array}$ & $\begin{array}{l}\text { Toxicity related to ligands } \\
\text { on gold nano-particles }\end{array}$ & In vitro \\
\hline \multirow[t]{4}{*}{ Magnetic Nanoparticles [37] } & \multirow[t]{4}{*}{ Sienna+ magnetic nanoparticles } & \multirow{4}{*}{$\begin{array}{l}\text { Enhancement of Sentinel Lymph Node } \\
\text { Biopsies (SLNB) }\end{array}$} & Rash & \multirow[t]{4}{*}{ MELAMAG study } \\
\hline & & & Itchiness & \\
\hline & & & Dizziness & \\
\hline & & & Skin discolouration & \\
\hline $\begin{array}{l}\text { Superparamagnetic iron oxide } \\
\text { (SPIO) }[38,39]\end{array}$ & SPIO & $\begin{array}{l}\text { Enhancement of Sentinel Lymph Node } \\
\text { Biopsies (SLNB) }\end{array}$ & n/a & SENTIMAG study \\
\hline $\begin{array}{l}\text { Superparamagnetic } \\
\text { carbodextran-coated iron } \\
\text { oxide [40] }\end{array}$ & DS-SPION & Enhancement of MRI/PET scan & n/a & In vitro \\
\hline \multicolumn{5}{|l|}{ Drug Delivery Systems } \\
\hline \multirow[t]{4}{*}{ Liposomes [52] } & Cisplatin & \multirow{4}{*}{$\begin{array}{l}\text { Artificial vesicles consisting of an } \\
\text { aqueous core and outer phospholipid } \\
\text { layers; their aqueous core can be filled } \\
\text { with drugs }\end{array}$} & $\begin{array}{l}\text { Toxicity due to cationic } \\
\text { nature; }\end{array}$ & $\begin{array}{l}\text { Doxil (US) Myocet (UK) used } \\
\text { for ovarian CA and myeloma }\end{array}$ \\
\hline & Vincristine & & & \\
\hline & Doxorubicin & & Hand-foot syndrome & $\begin{array}{l}\text { Clinical trial for melanoma } \\
\text { showed ineffective. }\end{array}$ \\
\hline & & & & $\begin{array}{l}\text { NC-6004 (liposome-coated } \\
\text { Cisplatin) phase I trial Japan }\end{array}$ \\
\hline $\begin{array}{l}\text { Albumin-coated nanoparticles } \\
\text { [55] }\end{array}$ & Paclitaxel with Abrexane (albumin coat) & Drug Delivery System & $\mathrm{n} / \mathrm{a}$ & $\begin{array}{l}8 \text { clinical trials underway for } \\
\text { melanoma }\end{array}$ \\
\hline $\begin{array}{l}\text { Antibody Drug Conjugates } \\
\text { (ADCs) [56] }\end{array}$ & $\begin{array}{l}\text { Brentuximab vedotin, Trasruzumab } \\
\text { emtansine }\end{array}$ & Drug Delivery System & $\mathrm{n} / \mathrm{a}$ & $\begin{array}{l}\text { No clinical studies in } \\
\text { melanoma }\end{array}$ \\
\hline $\begin{array}{l}\text { Antibody Drug Conjugates } \\
\text { (ADCs) [56] }\end{array}$ & $\begin{array}{l}\text { Monoclonal antibody (mAb)Ep1 bound } \\
\text { to ferritin cage encapsulating cisplatin } \\
\text { *HFt-Pt-Ep1) }\end{array}$ & $\begin{array}{l}\text { Binds to the human melanoma specific } \\
\text { antigen CSPG4 }\end{array}$ & $n / a$ & $\mathrm{n} / \mathrm{a}$ \\
\hline \multicolumn{5}{|l|}{ Molecular Targeting } \\
\hline \multirow[t]{4}{*}{ siRNA $[61-63,68]$} & CALAA-01 & \multirow[t]{4}{*}{$\begin{array}{l}\text { Interfere with DNA and protein } \\
\text { synthesis and work by gene silencing }\end{array}$} & \multirow{4}{*}{$\begin{array}{l}\text { Silencing on unintended } \\
\text { RNA/ unable to transfer } \\
\text { enough siRNA }\end{array}$} & \multirow[t]{4}{*}{ CALAA-01 trial } \\
\hline & GSK2141795 & & & \\
\hline & APN401 & & & \\
\hline & Dendritic cells & & & \\
\hline $\begin{array}{l}\text { Melanoma specific cell marker } \\
{[69,70]}\end{array}$ & $\begin{array}{l}\text { gold nanospheres to the alpha- } \\
\text { melanocyte-stimulating hormone (MSH) } \\
\text { analog, a potent agonist of MC1R }\end{array}$ & $\begin{array}{l}\text { Used as cell markers and } \\
\text { photothermal ablation. }\end{array}$ & n/a & $\mathrm{n} / \mathrm{a}$ \\
\hline \multicolumn{5}{|l|}{ Immunotherapy } \\
\hline Vaccine [74] & $\begin{array}{l}\text { HAM (hyperacute melanoma } \\
\text { immunotherapy) }\end{array}$ & $\begin{array}{l}\text { The cellular components (HAM-1, } \\
\text { HAM-2, and HAM-3) of HyperAcute- } \\
\text { Melanoma immunotherapy have been } \\
\text { derived from allogeneic melanoma } \\
\text { cancer cell lines. }\end{array}$ & $\begin{array}{l}\text { Asthenia, Chills, } \\
\text { dehydration, diarrhoea, } \\
\text { fatigue, malaise }\end{array}$ & HAM trial \\
\hline $\begin{array}{l}\text { Immunomodulator delivery } \\
\text { vector [72] }\end{array}$ & $\begin{array}{l}\text { N-propionyl cysteaminylphenol- } \\
\text { maleimide-dextran (NPCMD) }\end{array}$ & $\begin{array}{l}\text { The immuno-potentiating effect } \\
\text { mediated by TLR4 and NLRP3 . }\end{array}$ & $\mathrm{n} / \mathrm{a}$ & $\mathrm{n} / \mathrm{a}$ \\
\hline
\end{tabular}


Citation: Lloyd-Hughes H, Shiatis AE, Pabari A, Mosahebi A, Seifalian A (2015) Current and Future Nanotechnology Applications in the Management of Melanoma: A Review. J Nanomed Nanotechnol 6: 334. doi:10.4172/2157-7439.1000334

Page 10 of 12

\begin{tabular}{|c|c|c|c|c|}
\hline \multirow[t]{10}{*}{ Nanopolymer [75] } & \multirow{10}{*}{$\begin{array}{l}\text { low molecular weight polyethylenimine } \\
(600 \mathrm{Da}) \text { linked by } \beta \text {-cyclodextrin and } \\
\text { conjugated with folate (named } \mathrm{H} 1 \text { ) }\end{array}$} & \multirow{10}{*}{$\begin{array}{l}\text { Nanopolymer used to deliver IL2 to } \\
\text { affected tissues hence stimulating } \\
\text { activation and proliferation of CD8+, } \\
\text { CD4+ T cell, and natural killer cells } \\
\text { and increasing the integration of these } \\
\text { into the tumor environment }\end{array}$} & IL2 - side effects: & \multirow[t]{10}{*}{ n/a } \\
\hline & & & flu-like symptom & \\
\hline & & & hypotension & \\
\hline & & & nausea/vomiting & \\
\hline & & & diarrhea & \\
\hline & & & fatigue & \\
\hline & & & confusion & \\
\hline & & & shortness of breath & \\
\hline & & & rash & \\
\hline & & & low urine output & \\
\hline Drug delivery system & $\begin{array}{l}\text { Nanoporous Silica Microparticle } \\
\text { (NSiO(2)-MP) }\end{array}$ & $\begin{array}{l}\text { A drug delivery system and scaffolding } \\
\text { platoform that activates Toll like } \\
\text { Receptors (TLR) and macrophages. }\end{array}$ & As above & $n / a$ \\
\hline Vaccine & Exosomes & $\begin{array}{l}\text { Exosomes can be used for both } \\
\text { diagnostic and therapeutic agents } \\
\text { (vaccine) }\end{array}$ & $\mathrm{n} / \mathrm{a}$ & $n / a$ \\
\hline \multicolumn{5}{|l|}{ Photodynamic Therapy } \\
\hline Nanocarriers & $\begin{array}{l}\text { Shells of charged biocompatible } \\
\text { polymers grafted on gold nanospheres }\end{array}$ & $\begin{array}{l}\text { They can be labelled with a } \\
\text { fluorescent photosensitizer and offer } \\
\text { high local loading enhancing the use } \\
\text { of Photodynamic Therapy }\end{array}$ & $\mathrm{n} / \mathrm{a}$ & $n / a$ \\
\hline $\begin{array}{l}\text { Nanomaterial-induced } \\
\text { photodynamic therapy [81] }\end{array}$ & Gold nanoechinus & $\begin{array}{l}\text { Gold nanoechinus can form singlet } \\
\text { oxygen leading to photodynamic and } \\
\text { photothermal therapeutic effect }\end{array}$ & n/a & $n / a$ \\
\hline \multicolumn{5}{|l|}{ Photothermal Therapy } \\
\hline Delivery carrier [80] & $\begin{array}{l}\text { Nanographene oxide-Hyaluronic Acid } \\
\text { conjugate (NGO-HA) }\end{array}$ & $\begin{array}{l}\text { Transdermal delivery of NGO-HA to } \\
\text { tumor tissues enabling the enhanced } \\
\text { penetration of NIR irradiation. }\end{array}$ & n/a & $n / a$ \\
\hline \multicolumn{5}{|l|}{ Theranostics } \\
\hline Nanogels [82] & $\begin{array}{l}\text { Ag-Au bimetallic NP core with } \\
\text { a thermo-responsive nonlinear } \\
\text { poly(ethylene glycol) (PEG)-based } \\
\text { hydrogel shell }\end{array}$ & $\begin{array}{l}\text { Imaging; release of temozolimide to } \\
\text { target cells; photothermal therapy }\end{array}$ & n/a & $n / a$ \\
\hline Carbon Nanotubes $[81,82]$ & $\begin{array}{l}\text { a tubular structure composed of sheets } \\
\text { of benzene rings }\end{array}$ & $\begin{array}{l}\text { Used as contrast agent for PET scans } \\
\text { but also as biomarkers. }\end{array}$ & n/a & $n / a$ \\
\hline $\begin{array}{l}\text { Magnetic Carbon nanotubes } \\
\text { [80-82] }\end{array}$ & As above & $\begin{array}{l}\text { They are conjugated to } \\
\text { chemotherapeutic agents to provide } \\
\text { treatment of lymphatic melanoma } \\
\text { metastasis and SNLB (88). There is } \\
\text { also a great scope for use as drug } \\
\text { delivery systems, photodynamic } \\
\text { therapy and gene }\end{array}$ & n/a & $n / a$ \\
\hline
\end{tabular}

Table 2: Various nanoparticles loaded with different combinations of drugs targeting melanoma are continuously being developed indicating great hope for the future of nano-drug delivery platforms for advanced melanoma.

high loading capacity for temozolomide and offer a thermo-triggered drug release. The scope for nanoparticles as theranostics is endless.

Exosomes, small biological membrane vesicles, are molecules of double-edged features that are being investigated as both diagnostic and therapeutic agents due to their potential use as biological markers for certain cancers, as well as drug delivery systems. They have also been studied as agents that could formulate pioneer cancer vaccines that could control carcinogenesis via immunomodulation [77].

Various other inorganic nanomaterials, including nanocrystals, nanotubes and nanowires have been designed as multi-potent devices in the field of theranostics. Of these, carbon nanotubes (CNT), a tubular structure composed of sheets of benzene rings, have various properties that make it an excellent molecule not only for diagnostic purposes, but also therapeutic in the form of phototherapy as well as cellular therapy [78-80]. CNTs have been used as a contrast agent in PET scans for molecular imaging and were found to have 100-times efficacy when compared to traditional contrasts [81].

Magnetic Carbon nanotubes [MWCNTs] have been shown to have a satisfactory lymphatic distribution and have also been conjugated to chemotherapeutic agents to provide treatment of lymphatic melanoma metastasis and SNLB [82]. There is also a great scope for use as drug delivery systems, photodynamic therapy and gene therapy.

\section{Conclusion}

Melanoma still remains a killer disease. As more advances are made in understanding its molecular profile and pathogenesis, more scope for early diagnostic and effective treatment presides. Nanotechnology has the potential to improve both the diagnosis and treatment of this disease. Combining nanoparticles with new advances in diagnosis, in addition to the biological and chemical therapies has immense scope and potential. Nanotechnology has already shown to be efficient in delivering anticancer drugs, improving efficacy and reducing side effects.

Nanoparticles are successfully used to carry imaging agents for melanoma detection and specific mutation silencing. Exciting and encouraging research is being published on a daily basis in the field of nano-oncology and there is successful translation into clinical 
Citation: Lloyd-Hughes H, Shiatis AE, Pabari A, Mosahebi A, Seifalian A (2015) Current and Future Nanotechnology Applications in the Management of Melanoma: A Review. J Nanomed Nanotechnol 6: 334. doi:10.4172/2157-7439.1000334

practice. More information is however required on the long-term safety and toxicity of these applications and more work are required on combining the most promising therapies such as ipilimumab with nanoparticles. Ipilimumab, marketed as Yervoy, is a drug used for the treatment of cancer. It has been approved in the U.S. by FDA for the treatment of melanoma since 2011. More clinical studies underway at present are summarized in Table 2.

One thing is sure, nanotechnology is a promising filed, providing hope for the future in the worldwide quest for curing melanoma. Nanoparticle by nanoparticle may we achieve this goal.

\section{References}

1. Siegel R, DeSantis C, Virgo K, Stein K, Mariotto A, et al. (2012) Cancer treatment and survivorship statistics. CA Cancer J Clin 62: 220-241.

2. Siegel R, Naishadham D, Jemal A (2012) Cancer statistics, 2012. CA: a cancer journal for clinician 62: 10-29.

3. Zitelli JA, Mohs FE, Larson P, Snow S (1989) Mohs micrographic surgery for melanoma. Dermatol Clin 7: 833-843.

4. Hodi FS, O'Day SJ, McDermott DF, Weber RW, Sosman JA, et al. (2010) Improved survival with ipilimumab in patients with metastatic melanoma. N Engl J Med 363: 711-723.

5. Bombelli FB, Webster CA, Moncrieff M, Sherwood V4 (2014) The scope of nanoparticle therapies for future metastatic melanoma treatment. Lancet Onco 15: e22-32.

6. Marsden JR, Newton-Bishop JA, Burrows L, Cook M, Corrie PG, et al. (2010) Revised UK guidelines for the management of cutaneous melanoma 2010 . $J$ Plast Reconstr Aesthet Surg 63: 1401-1419.

7. Morton DL, Thompson JF, Cochran AJ, Mozzillo N, Nieweg OE, et al. (2014) Final trial report of sentinel-node biopsy versus nodal observation in melanoma. N Engl J Med 370: 599-609.

8. Nikolaou VA, Stratigos AJ, Flaherty KT, Tsao H (2012) Melanoma: new insights and new therapies. J Invest Dermatol 132: 854-863.

9. Jha G, Miller JS, Curtsinger JM, Zhang Y, Mescher MF, et al. (2014) Randomized phase II study of IL-2 with or without an allogeneic large multivalent immunogen vaccine for the treatment of stage IV melanoma. Am J Clin Oncol 37: 261-265.

10. Schadendorf D, Vaubel J, Livingstone E, Zimmer L (2012) Advances and perspectives in immunotherapy of melanoma. Ann Oncol 23 Suppl 10: x104-108.

11. Mackiewicz-Wysocka M, Zolnierek J, Wysocki PJ (2013) New therapeutic options in systemic treatment of advanced cutaneous melanoma. Expert Opin Investig Drugs 22: 181-190.

12. Michalet X, Pinaud FF, Bentolila LA, Tsay JM, Doose S, et al. (2005) Quantum dots for live cells, in vivo imaging, and diagnostics. Science 307: 538-544.

13. Kim MJ, Lee JY, Nehrbass U, Song R, Choi Y (2012) Detection of melanoma using antibody-conjugated quantum dots in a coculture model for highthroughput screening system. Analyst 137: 1440-1445.

14. Rizvi SB, Ghaderi S, Keshtgar M, Seifalian AM (2010) Semiconductor quantum dots as fluorescent probes for in vitro and in vivo bio-molecular and cellular imaging. Nano Rev 1.

15. Zheng H, Chen G, DeLouise LA, Lou Z (2010) Detection of the cancer marker CD146 expression in melanoma cells with semiconductor quantum dot label. $J$ Biomed Nanotechnol 6: 303-311.

16. Ghaderi S, Ramesh B, Seifalian AM (2012) Synthesis of mercaptosuccinic acid/MercaptoPolyhedral oligomeric silsesquioxane coated cadmium telluride quantum dots in cell labelling applications. J Nanosci Nanotechnol 12: 49284935.

17. Chen LD, Liu J, Yu XF, He M, Pei XF, et al. (2008) The biocompatibility of quantum dot probes used for the targeted imaging of hepatocellular carcinoma metastasis. Biomaterials 29: 4170-4176.

18. Kirchner C, Javier AM, Susha AS, Rogach AL, Kreft O, et al. (2005) Cytotoxicity of nanoparticle-loaded polymer capsules. Talanta $67: 486-491$.

19. Lovria J, Bazzi HS, Cuie Y, Fortin GR, Winnik FM, et al. (2005) Differences in subcellular distribution and toxicity of green and red emitting CdTe quantum dots. J Mol Med (Berl) 83: 377-385.

20. Shiohara A, Hoshino A, Hanaki K, Suzuki K, Yamamoto K (2004) On the cytotoxicity caused by quantum dots. Microbiol Immunol 48: 669-675.

21. Rizvi SB, Yildirimer L, Ghaderi S, Ramesh B, Seifalian AM, et al. (2012) A novel POSS-coated quantum dot for biological application. Int J Nanomedicine 7: 3915-3927.

22. Yaghini E, Giuntini F, Eggleston IM, Suhling K, Seifalian AM, et al. (2014) Fluorescence lifetime imaging and FRET-induced intracellular redistribution of Tat-conjugated quantum dot nanoparticles through interaction with a phthalocyanine photosensitiser. Small 10: 782-792.

23. (2014) Fluorescence lifetime imaging and FRET -induced intracellular redistribution of Tat-conjugated quantum dot nanoparticles through interaction with a phthalocyanine photosensitiser. Small 26: 782-792.

24. Bradbury MS, Phillips E, Montero PH, Cheal SM, Stambuk H, et al. (2013) Clinically-translated silica nanoparticles as dual-modality cancer-targeted probes for image-guided surgery and interventions. Integr Biol (Camb) 5: 74-86.

25. Clinically-translated silica nanoparticles as dual-modality cancer-targeted probes for image-guided surgery and interventions. Integrative biology: quantitative biosciences from nano to macro PubMed PMID: 23138852. 5: 74-86.

26. Benezra M, Penate-Medina O, Zanzonico PB, Schaer D, Ow H, et al. (2011) Multimodal silica nanoparticles are effective cancer-targeted probes in a mode of human melanoma. J Clin Invest 121: 2768-2780.

27. Friedman R (2011) Nano dot technology enters clinical trials. J Natl Cancer Inst 103: $1428-1429$

28. Kim C, Cho EC, Chen J, Song KH, Au L, et al. (2010) In vivo molecula photoacoustic tomography of melanomas targeted by bioconjugated gold nanocages. ACS Nano 4: 4559-4564

29. Grimfors G, Schnell PO, Holm G, Johansson B, Mellstedt H, et al. (1989) Tumour imaging of indium-111 oxine-labelled autologous lymphocytes as a staging method in Hodgkin's disease. Eur J Haematol 42: 276-283.

30. Jain S, Hirst DG, O'Sullivan JM (2012) Gold nanoparticles as novel agents for cancer therapy. The British journal of radiology 85: 101-113.

31. Pan D, Pramanik M, Senpan A, Wickline SA, Wang LV, et al. (2010) A facile synthesis of novel self-assembled gold nanorods designed for near-infrared imaging. J Nanosci Nanotechnol 10: 8118-8123.

32. Pan D, Kim B, Wang LV, Lanza GM (2013) A brief account of nanoparticle contrast agents for photoacoustic imaging. Wiley interdisciplinary reviews Nanomedicine and nanobiotechnology. 5: 517-543.

33. Johnson L, Pinder SE, Douek M (2013) Deposition of superparamagnetic ironoxide nanoparticles in axillary sentinel lymph nodes following subcutaneous injection. Histopathology 62: 481-486.

34. Bull E, Madani SY, Sheth R, Seifalian A, Green M, et al. (2014) Stem cell tracking using iron oxide nanoparticles. Int J Nanomedicine 9: 1641-1653.

35. Urban C, Urban AS, Charron H, Joshi A (2013) Externally modulated theranostic nanoparticles. Transl Cancer Res 2: 292-308.

36. Vanneman M, Dranoff G (2012) Combining immunotherapy and targeted therapies in cancer treatment. Nat Rev Cancer 12: 237-251.

37. Zhang X, Chibli H, Kong D, Nadeau J (2012) Comparative cytotoxicity of golddoxorubicin and InP-doxorubicin conjugates. Nanotechnology 23: 275103

38. Kottschade LA, Suman VJ, Perez DG, McWilliams RR, Kaur JS, et al. (2013) A randomized phase 2 study of temozolomide and bevacizumab or nabpaclitaxel, carboplatin, and bevacizumab in patients with unresectable stage IV melanoma : a North Central Cancer Treatment Group study, N0775. Cancer 119: 586-592.

39. Katipamula R, Markovic SN (2008) Emerging therapies for melanoma. Expert Rev Anticancer Ther 8: 553-560.

40. Chaudhuri P, Paraskar A, Soni S, Mashelkar RA, Sengupta S (2009) Fullerenolcytotoxic conjugates for cancer chemotherapy. ACS Nano 3: 2505-2514.

41. Ernsting MJ, Murakami M, Undzys E, Aman A, Press B, et al. (2012) A docetaxelcarboxymethylcellulose nanoparticle outperforms the approved taxane nanoformulation, Abraxane, in mouse tumor models with significant control of metastases. Journal of controlled release 162: 575-581. 
Citation: Lloyd-Hughes H, Shiatis AE, Pabari A, Mosahebi A, Seifalian A (2015) Current and Future Nanotechnology Applications in the Management of Melanoma: A Review. J Nanomed Nanotechnol 6: 334. doi:10.4172/2157-7439.1000334

Page 12 of 12

42. Hu CM, Zhang L (2012) Nanoparticle-based combination therapy toward overcoming drug resistance in cancer. Biochem Pharmacol 83: 1104-1111.

43. Arora HC, Jensen MP, Yuan Y, Wu A, Vogt S, et al. (2012) Nanocarriers enhance Doxorubicin uptake in drug-resistant ovarian cancer cells. Cancer Res 72: 769-778.

44. Li J, Wang Y, Liang R, An X, Wang K, et al. (2015) Recent advances in targeted nanoparticles drug delivery to melanoma. Nanomedicine 11: 769-794.

45. Parhi P, Mohanty C, Sahoo SK (2012) Nanotechnology-based combinational drug delivery: an emerging approach for cancer therapy. Drug Discov Today 17: 1044-1052.

46. Dilnawaz F, Singh A, Mohanty C, Sahoo SK (2010) Dual drug loaded superparamagnetic iron oxide nanoparticles for targeted cancer therapy. Biomaterials 31: 3694-3706.

47. Tran MA, Watts RJ, Robertson GP (2009) Use of liposomes as drug delivery vehicles for treatment of melanoma. Pigment Cell Melanoma Res 22: 388-399.

48. Guo S, Wang Y, Miao L, Xu Z, Lin CH, et al. (2014) Turning a water and oi insoluble cisplatin derivative into a nanoparticle formulation for cancer therapy. Biomaterials 35: 7647-7653.

49. Plummer R, Wilson RH, Calvert H, Boddy AV, Griffin M, et al. (2011) A Phase clinical study of cisplatin-incorporated polymeric micelles (NC- 6004) in patients with solid tumours. British journal of cancer. 104: 593-598.

50. Ciruelos E, Jackisch C (2014) Evaluating the role of nab-paclitaxel (Abraxane) in women with aggressive metastatic breast cancer. Expert Rev Anticancer Ther 14: 511-521.

51. Falvo E, Tremante E, Fraioli R, Leonetti C, Zamparelli C, et al. (2013) Antibodydrug conjugates: targeting melanoma with cisplatin encapsulated in proteincage nanoparticles based on human ferritin. Nanoscale 5: 12278-12285.

52. Thakor AS, Gambhir SS (2013) Nanooncology: the future of cancer diagnosis and therapy. CA Cancer J Clin 63: 395-418.

53. Ameres SL, Martinez J, Schroeder R (2007) Molecular basis for target RNA recognition and cleavage by human RISC. Cell 130: 101-112.

54. Miele E, Spinelli GP, Miele E, Di Fabrizio E, Ferretti E, et al. (2012) Nanoparticlebased delivery of small interfering RNA: challenges for cancer therapy. Int $J$ Nanomedicine 7: 3637-3657.

55. Masiero M, Nardo G, Indraccolo S, Favaro E (2007) RNA interference: implications for cancer treatment. Mol Aspects Med 28: 143-166.

56. Rigel DS, Russak J, Friedman R (2010) The evolution of melanoma diagnosis: 25 years beyond the ABCDs. CA Cancer J Clin 60: 301-316.

57. Alshamsan A, Hamdy S, Samuel J, El-Kadi AO, Lavasanifar A, et al. (2010) The induction of tumor apoptosis in B16 melanoma following STAT3 siRNA delivery with a lipid-substituted polyethylenimine. Biomaterials 31: 1420-1428.

58. Davis ME (2009) The first targeted delivery of siRNA in humans via a selfassembling, cyclodextrin polymer-based nanoparticle: from concept to clinic. Molecular pharmaceutics 6: 659-668.

59. Dannull J, Haley NR, Archer G, Nair S, Boczkowski D, et al. (2013) Melanoma immunotherapy using mature DCs expressing the constitutive proteasome. J Clin Invest 123: 3135-3145

60. Tran MA, Gowda R, Sharma A, Park EJ, Adair J, et al. (2008) Targeting V600EB-Raf and Akt3 using nanoliposomal-small interfering RNA inhibits cutaneous melanocytic lesion development. Cancer research 68: 7638-7649.

61. Spugnini EP, Biroccio A, De Mori R, Scarsella M, D'Angelo C, et al. (2011) Electroporation increases antitumoral efficacy of the bcl-2 antisense G3139 and chemotherapy in a human melanoma xenograft. Journal of translational medicine 9: 125

62. Ott PA, Chang J, Madden K, Kannan R, Muren C, et al. (2013) Oblimersen in combination with temozolomide and albumin-bound paclitaxel in patients with advanced melanoma: a phase I trial. Cancer Chemother Pharmacol 71: 183-191.

63. Basu S, Harfouche R, Soni S, Chimote G, Mashelkar RA, et al. (2009) Nanoparticle-mediated targeting of MAPK signaling predisposes tumor to chemotherapy. Proceedings of the National Academy of Sciences of the United States of America 106: 7957-7961.

64. Seong I, Kim J (2014) Gene expression regulation by agonist-independent constitutive signaling of melanocortin-1 receptor. Endocrinol Metab (Seoul) 29 . 179-184.

65. Lu W, Xiong C, Zhang G, Huang Q, Zhang R, et al. (2009) Targeted phototherma ablation of murine melanomas with melanocyte-stimulating hormone analogconjugated hollow gold nanospheres. Clin Cancer Res 15: 876-886.

66. Zhang Z, Tongchusak S, Mizukami Y, Kang YJ, loji T, et al. (2011) Induction of anti-tumor cytotoxic $T$ cell responses through PLGA-nanoparticle mediated antigen delivery. Biomaterials 32: 3666-3678.

67. Stephan MT, Moon JJ, Um SH, Bershteyn A, Irvine DJ (2010) Therapeutic cell engineering with surface-conjugated synthetic nanoparticles. Nat Med 16 1035-1041.

68. Mizote Y, Wakamatsu K, Ito S, Uenaka A, Ohue Y, et al. (2014) TLR4 and NLRP3 inflammasome activation in monocytes by $\mathrm{N}$-propionyl cysteaminylphenolmaleimide-dextran (NPCMD). J Dermatol Sci 73: 209-215.

69. Yao H, Ng SS, Huo LF, Chow BK, Shen Z, et al. (2011) Effective melanoma immunotherapy with interleukin-2 delivered by a novel polymeric nanoparticle. Mol Cancer Ther 10: 1082-1092.

70. Cejudo-Guillen M, Ramiro-Gutierrez ML, Labrador-Garrido A, Diaz-Cuenca A Pozo D (2012) Nanoporous silica microparticle interaction with toll-like receptor agonists in macrophages. Acta biomaterialia 8: 4295-4303.

71. Baldea I, Filip AG (2012) Photodynamic therapy in melanoma an update. J Physiol Pharmacol 63: 109-118.

72. Navarro JR, Lerouge F, Cepraga C, Micouin G, Favier A, et al. (2013) Nanocarriers with ultrahigh chromophore loading for fluorescence bio-imaging and photodynamic therapy. Biomaterials 34: 8344-8351.

73. Vijayaraghavan P, Liu CH, Vankayala R, Chiang CS, Hwang KC (2014) Designing Multi- Branched Gold Nanoechinus for NIR Light Activated Dual Modal Photodynamic and Photothermal Therapy in the Second Biological Window. Advanced materials 26: 6689-6695.

74. Samia AC, Dayal S, Burda C (2006) Quantum dot-based energy transfer: perspectives and potential for applications in photodynamic therapy. Photochem Photobiol 82: 617-625.

75. Jung HS, Kong WH, Sung DK, Lee MY, Beack SE, et al. (2014) Nanographene oxide-hyaluronic acid conjugate for photothermal ablation therapy of skin cancer. ACS Nano 8: 260-268.

76. Chu M, Pan X, Zhang D, Wu Q, Peng J, et al. (2012) The therapeutic efficacy of $\mathrm{CdTe}$ and $\mathrm{CdSe}$ quantum dots for photothermal cancer therapy. Biomaterials 33: 7071-7083.

77. Wenjie D, Yongsheng Li, Dechao N, Zhi M, Jinlou G, et al. (2011) Theranostic Nanoshells: Facile Synthesis of Monodisperse Supermagnetic Fe3O4 Core Hybrid Au Shell Nanocomposite for Bimodal Imaging and Photothermal Therapy. Advance Materials 23: 5332

78. Wu W, Shen J, Gai Z, Hong K, Banerjee P, et al. (2011) Multi-functional coreshell hybrid nanogels for $\mathrm{pH}$-dependent magnetic manipulation, fluorescent $\mathrm{pH}$-sensing, and drug delivery. Biomaterials 32: 9876-9887.

79. Natasha G, Gundogan B, Tan A, Farhatnia Y, Wu W, et al. (2014) Exosomes as immunotheranostic nanoparticles. Clin Ther 36: 820-829.

80. Kam NW, O'Connell M, Wisdom JA, Dai H (2005) Carbon nanotubes as multifunctional biological transporters and near-infrared agents for selective cancer cell destruction. Proc Natl Acad Sci USA 102: 11600-11605

81. Yu X, Munge B, Patel V, Jensen G, Bhirde A, et al. (2006) Carbon nanotube amplification strategies for highly sensitive immunodetection of cancer biomarkers. J Am Chem Soc 128: 11199-11205.

82. Naderi N, Madani SY, Ferguson E, Mosahebi A, Seifalian AM (2013) Carbon nanotubes in the diagnosis and treatment of malignant melanoma. Anticancer Agents Med Chem 13: 171-185. 